\title{
Modern Approaches to Publicity and Independence of Local Government: Experience of American Municipalities
}

\author{
Tatiana N. Mikheeva \\ Artem O. Likhoshva
}

Mari State University, Yoshkar-Ola, Russia; Email: TNMiheeva@marsu.ru

\section{Doi:10.5901/mjss.2016.v7n1s1p31}

\begin{abstract}
Publicity and independence are basic principles of the exercising local government. Due to them not only local problems can be solved openly and without interference from state bodies, but also local authorities can become closer to people in municipalities in order to solve these problems. The aim of this work is the investigation of American experience in the part of legal regulation and realization of publicity principle when people and municipal bodies solve local problems independently. Turning to the experience of the United States of America it is caused by some factors. Firstly, in this country durable and firm traditions are formed in the sphere of local government. Secondly, this country and Russia are united by the Anglo-Saxon model of local government, on which the organization of municipal power is based. Thirdly, both states are the largest federations, which are objectively difficult to govern from the federal centre. Without participation of citizens and bodies formed by them in processes of government solution of problems of providing local communities with life necessities it is impossible under modern conditions.A lot of international law acts, including European Charter of Local Self-Government, connect democracy with the local government as the effective government, which is close to citizens (European Charter of Local Self-Government, 1985). However, influence of the publicity principle on the processes of local government remains an underinvestigated scientific direction. As the result of considering the status of the problem under investigation in the local communities in the United States of America specific features of performing publicity and openness were discovered in the interrelation between authorities and people Characteristics of the American model of local government are pointed out. They may be recommended to be applied in the home municipal construction. In this connection, the investigation is new, it contains theoretical conclusions and positive experience, what brings new knowledge to science and practice of local government.
\end{abstract}

Keywords: local government, publicity, independence, municipality, citizens, local authorities.

\section{Introduction}

There is a problem of the participation of citizens of municipalities when exercising local government is still important. Home municipal practice shows increasing of the tendency to citizens' activity when local questions are solved. In this connection President of the Russian Federation in his Address to the Federal Assembly pointed out that citizens do not only take up matters with the power, but they also take part in their decision themselves and understand, that a lot of things depend on their efforts (Address by President of the Russian Federation, 2014).

Legal nature of local government, as it was mentioned in preceding works, lies in the matter that it is such a form of people power which allows those people who live on the local territory and are united by common interests to solve a certain range of questions independently and at their own risk (Mikheeva,2012). Problems which are solved at this level are close and clear to each resident. A. A. Yaroshenko truly mentions that local power is aimed at providing best conditions for people's life (Yaroshenko, 2002). Transparency of the running process is important when independency of this level of public authority is legislated. In this connection the problem of realizing publicity principle is especially significant in the system of local government (Kudryavtsev, Mikheeva, 2015). Its nature lies in transparency and openness of local bodies' activities for people, citizens' awareness of these activities. Scientists point out that publicity creates conditions for people's activeness according to place of their residence. In such way an important problem concerning ensuring effectiveness of local government is solved (Mikheev, Mikheeva, Mokoseeva, 2015). Publicity is to become the basis for interaction between local bodies and residents in the municipalities.

In this part foreign experience has a scientific interest. Referring to it, it would be possible to offer amendments to the home legal system, and the best practical patterns could be recommended to be applied in Russian local communities. D.S. Mikheev has opinion, that modern states consider publicity as the basic fundamental principle in legal 
regulation of local authority because publicity is an instrument connecting local bodies and residents in the municipalities. And these words by D.S. Mikheev can be considered as justified one (Mikheev, 2014).

Attention of many researches in the sphere of local government is focused on the positive experience of the large federation - the United States of America. In this federation the organization of local authority differs with the large independency of municipalities and their residents. The analysis of the American experience in this sphere can help to solve some national problems, as a lot of problems of Russia in this connection they are not exclusive. They are the signs of tendencies that are common for a lot of countries in world community (Salov, 2001).

\section{Methods}

Methodology of the investigation is based on the complex of scientific methods. Among them general scientific methods as well as specific methods, used by legal science, were applied. Special attention was paid to the dialectical method which allows considering legal and social phenomena in their logical interrelation. Here analysis and synthesis, analogy, moving from particulars to generals were needed.

Scientific objectivity was used for thorough and objective analysis of factual material about activities of American municipalities, involving citizens into these activities.

Discovering publicity principle or its elements became possible due to application of systematic-structural method in the work of public structures at the local level when municipal bodies take public opinion into account.

A comparative legal method was demanded within the investigation. With the help of this method a great deal of foreign material was studied and analyzed. This allows discovering certain laws and differences in the investigated issue in local communities of the USA. Evaluation of received knowledge revealed certain tendencies to creation of legal conditions, which leads to citizens' activity and their influence on decisions of local authorities.

In the work other scientific methods were also applied. They all formed the basis for research work and revealed the topic of investigation.

\section{Results and Discussion}

In independence of the local government publicity principle plays a great role. It is a key point in the relations of authority and people in local communities. It includes such important elements as people's access to information about the activities of municipal bodies, revealing and considering people's opinion during making local bodies' decisions, residents' opportunity to influence the process of making decisions by local bodies. People's opportunity to control activities of the bodies which were formed in the local community with citizens' participation is no less important. It is public control which is becoming one of priorities in the mechanism of realization of publicity principle nowadays (Mikheev, Dudko, Mikheeva, 2015).

According to R.V. Babun's opinion, attraction of initiative groups of citizens to the solution of local problems became the norm of municipal authorities' life in the countries with democracy (Babun, 2010). Realization of this publicity principle is closely connected with the problem of citizens' participation in exercising local government, openness of municipal structures and municipal workers for people, active attraction of citizens to processes of local life. In this connection experience of the United States of America has scientific interest, according to the opinion of the famous Russian scientist A. I. Vasilchikov, the USA is traditionally accepted as a state, based on local government, and the American principle of self-government was developed (Vasilchikov, 1872).

Though solution of problems of everyday life of American municipalities is the responsibility of local authorities, people also take part with interest in determining key directions of local life. Here the state itself is aimed at increasing people's interest in problems of local government, making municipal system more attractive for people. With this aim amendments are made in the legal system, they are directed at spreading publicity in municipal authorities' activities (Cherkasov, 2011).

During characterizing American municipal charters G.V. Barabashev points out their direction at contributing in the formation of correct and full people's ideas about how the mechanism of local government is formed and functioned, how citizens can control it and take part in its work (Barabashev, 1996). As a matter of fact, scientists pay much attention to the institution of control with reference to the problem under investigation. On the one hand, it lets a local community get the idea about local authorities' activities, their functions, and, on the other hand, it reveals drawbacks in activities of local authorities in order to increase effectiveness of their work during solving local questions (Belousov, Gornev, Mikheeva, 2015).

In the municipal sphere experience of the United States of America shows the intention of the state and municipal 
bodies for including residents in the process of independent decision-making at the local level through the most transparency of municipal activities. It is possible when publicity as an important principle of local government is observed. Russian scientists have already been spoken about the spread of local government's new conception in the activities of local government in democratic countries for two decades. This conception is characterized by the intention in order to help separate people or groups to meet their needs themselves (Strashun, 1996). The inherent element of the American local government is also the existence of the citizen's national tradition and they rely on themselves without waiting for government's or any group's own point of view, step, but they take this step themselves, on their own initiative and at their own risk (Batalov, 1990).

Russian researches explain this specific feature of American citizens by the fact that local authorities were formed much earlier than the federation and they were only a little improved by local and federal legislators (Grafsky, Yefremova, 1995). However, in spite of established traditions, in the USA the degree of people's participation in local government was also changed. It should be pointed out that modern approaches were formed in the 70-ties of the 20-th century, when processes, connected with the formation of new public structures at the local level and renewal of voluntary organizations, tested in previous historical periods, became active. According to Y.A. Neznamova such organizations were formed with an aim to increase effectiveness of district service, to ensure interaction between people and authorities, to reduce complaints about activities of local authorities (Neznamova, 2009). The status of these organizations has a resemblance to territorial public self-government in Russia.

At the same time there are a lot of differences in their formation and activities. Local public bodies that function in blocks in cities (Blockorganization) can be defined as the most close to the home territorial self-government. As a rule, they unite residents of one or several streets. In Russian territorial public self-government such unification is taking place on the local territories of a house, a street, a block, a micro district. The aims of formation of such bodies are also similar. They keep courtyard and adjacent territories clean, equip playgrounds and maintain public order etc. American voluntary organizations differ with their systemacity that is evident from the systematic meetings of residents, involvement of representatives of city council in these meetings. The characteristic feature is also the intention to unite efforts of residents and local authorities for improvement of the situation on the mentioned local territories. Though the participation in these organizations is voluntary and free, they are widely spread. In the above-mentioned work Y.A. Neznamova says that in New York, for example, there are more than 10000 such voluntary organizations.

Functioning of these organizations is based on independency and wide publicity. They are formed on the citizens' initiative and seek for openness when local problems are discussed, involvement of as many citizens as possible in the improvement of the life of a block. With the help of publicity not only citizens are fully informed, but also conditions for cooperation of citizens and municipal bodies are created. It should be pointed out that the latter has a huge interest in supporting independent initiatives of people and local organizations in a block. A foreign investigator G. Hyden expresses a similar point of view and mentions that democracy and further development of local government are impossible without legal enforcement of effective and powerful forms of interaction between local authorities and public associations that operate at the local level and comprise more active and responsible citizens of the municipal entity (Hyden G., 1997). Voluntary associations, which are similar in tasks, exist on larger municipal territories - in the American city districts which activities are also aimed at uniting citizens for solving important local problems within the district.

At the same time, public organizations, formed for solving only one functional task on the municipal territory stand out against the public variety at the local level. Tasks, which unite members of these organizations, can be health care of local people, protection of the environment, provision of housing for citizens, policing and prevention of wrong. All the activities are again based on the principles of independency, transparency, awareness of all the people.The characteristic feature is a participation of organizations' members as well as other residents in making decisions by a municipality on a certain problem. Here wide publicity and independence of residents can be also observed. Concentration on one task, problem doesn't change approaches to its decision on the whole. In its realization municipal bodies are included . they are responsible for this question. Common discussions, enquiries, reports of administrators of a municipality to citizens on fulfillment of the task, consultations are used for that.

Attention should be also paid to the involvement of a widely developed system of public bodies, which are formed by municipalities as advisory (Neighborhood Council) in the municipal home practice. They are also aimed at enhancing cooperation of local bodies and residents. Advisory commissions are directly elected by residents. That's why they are independent from municipal bodies. Their main aim is making recommendations for municipal bodies on problems, concerning interests of residents in local communities. Among them there are small matters (removal of household waste, sanitation condition of territories of car parking), as well as there are more serious problems of economic development, local budget, local taxes.

Though commissions are formed as advisory bodies in municipalities, the responsibility of local authorities to 
inform these commissions during making decisions concerning people's interests is fixed in law. Y.A. Neznamova points out that opinion of the commission plays an important role when local bodies make the final decision. It includes advisory commissions to the system of local authorities as closer representatives of municipal power to people, which provide residents with the opportunity to influence the city policy directly (Neznamova, 2009). Despite the fact that participation of members in the work of advisory commissions is free, however there is an opportunity to hire career servants when qualified decisions and assisting members of these commissions are prepared.

In the given example a lot of elements of independence and publicity of local government are evident. They are openness of activities of municipalities, people's access to the information about these activities, residents' independence in electing advisory commissions, the possibility to exercise public control over decisions by people represented by members of advisory commissions, and also taking into account residents' opinion when they make decisions. They concern to representative bodies and also to executive municipal bodies.

\section{Conclusion}

Summing up the American municipal experience in the investigated problem, some conclusions should be made. Though in acts of legislation of states and municipal charters, which determine formation and activities of local government, such important principles as publicity and independence of local government are not directly fixed, but legal conditions for citizens' participation in local life fell under regulation. In view of historically developed traditions of self-government in the American model of local government following points are evident:

- citizens' active independent involvement in the solution of problems on municipal territories, or their local parts (blocks, districts in cities);

- the intention of municipal bodies to cooperate tightly with people and local public organizations, formed by them, when local problems are defined;

- independent formation of public advisory organizations by people and their further involvement in the system of local authorities. These organizations are independent bodies which express public opinion when making important local decisions.

Elements, mentioned above, are fully comprised by the principle of publicity of local government. The abovementioned matters let us conclude that the realization of publicity principle leads to active involvement of citizens in government of municipalities, in the process of decision-making on local problems, taking into account local communities' interests.

Speaking about the independence of local government when public power is exercised at the local level, it should be mentioned, that it is impossible without such an important element as publicity. The investigation of practice of American municipalities' activities shows that their success is based on the openness of their activities for residents in local community, on the one hand, and readiness for supporting any sign of independent initiatives by citizens, on the other hand. The traditional intention of citizens to solve some small questions with their own efforts for more comfortable living in their house, courtyard, district is also evident.

Referring to this sphere of relations in home local government, it should be mentioned that residents show independence during solving local problems, specifically, through participation in municipal elections when the elect officers and local authorities. Cases of personal activity and interest in solving some local problems are rather rare. To overcome this passivity of Russian citizens, measures on wider openness and publicity of local authorities' activities, awareness of better practices of citizens' participation in local matters, including positive solution of these problems in American municipalities become evident.

\section{Acknowledgements}

The authors are grateful to the Russian Humanitarian Science Foundation (URL: http://www.rfh.ru/index.php/ru/) because of which financial and organizational support this investigation was conducted within the scientific project № 15-33-01364.

\section{References}

Barabashev, G. V. (1996). Local self-government, M., 226.

Baboon, R.V. (2010). Organization of local government. Moscow: KnoRus, 97.

Cherkasov, A.S. (2011). Local control in foreign countries: patterns and trends of evolution. State and Law, 3, 81.

European Charter of Local Self-Government, adopted by the Council Of Europe on October 15th, 1985. (1985). Legislation Bulletin of the 
Russian Federation. Issue 36, 4466.

Grafsky, V. G., Yefremova N. N.(1995). Institution of self-government: historical-legal investigation. M.: Nauka, 191.

Hyden, G. (1997). Civil society, social capital, and development: Dissection of a complex discourse. Studies in Comparative International Development, 32 (1), 3-30. DOI:10/1007/BF02696304

Kudryavtsev, V.V., Mikheeva, T.N. (2015). Publicity at the Formation of Municipal Authorities of European States. Mediterranean Journal of Social Sciences, Vol. 6, No 3 S7, 419-424.

Mikheev, D.S. (2014). Legal Analysis of the European Charter of the Local Self-Government in the Light of the Principle of Publicity. Life Science Journal, 11(6), 619-622.

Mikheev, D.S., Mikheeva, T.N., Mokoseeva, M.A. (2015). On the experience of legal regulation of the principle of local authorities in German law. Review of European Studies. Volume 7, No 8, 23-27, http//dx.doi.org/: 10.5539/res.v7n8p23.

Mikheev, D.S., Dudko, I.G., Mikheeva, T.N., (2015) Public Control in the Mechanism of Realization of the Principle of Local Authority Publicity. Mediterranean Journal of Social Sciences, Vol. 6, No 3 S7, 41-46.

Mikheeva, T.N. (2012). Peculiarities of the modern institution of local government in the Russian Federation. The Journal of Eurasian Law. 2, 58-59.

Neznamova, Y. A.(2009) Legal regulation of people's participation in local government in foreign countries. Administrative and municipal law, $2,5$.

Neznamova, E.A., (2009). Local self-government: past, present, future. Moscow: ed. Russian Academy of Public Service, 183-184.

Presidential Address to the Federal Assembly on 4 December 2014 (2014).RossiyskayaGazeta, 5 December.

Salov, O. A. (2001). Local self-government today. M.: Economica, 40.

Strashun, B.A. (1996). Constitutional (state) law of foreign countries. M.: Publishing house Beck, 700.

Vasilchikov, A. I. (1872). On the self-governing. Comparative review of Russian and foreign local and public agencies, SPb. V.1, 60-62.

Yaroshenko, A.A. (2002). Local government in the system of state power. State power and local government, 7, 37. 